\title{
Paideusis
}

\section{Russell Versus Dewey on Democracy}

\section{Michael J. Rockler}

Volume 10, Number 2, 1997

URI: https://id.erudit.org/iderudit/1073179ar

DOI: https://doi.org/10.7202/1073179ar

See table of contents

Publisher(s)

Canadian Philosophy of Education Society

ISSN

0838-4517 (print)

1916-0348 (digital)

Explore this journal

Cite this article

Rockler, M. (1997). Russell Versus Dewey on Democracy. Paideusis, 10(2), 3-11.

https://doi.org/10.7202/1073179ar

This document is protected by copyright law. Use of the services of Erudit (including reproduction) is subject to its terms and conditions, which can be viewed online.

https://apropos.erudit.org/en/users/policy-on-use/
This article is disseminated and preserved by Érudit.

Érudit is a non-profit inter-university consortium of the Université de Montréal, Université Laval, and the Université du Québec à Montréal. Its mission is to promote and disseminate research.

https://www.erudit.org/en/ 


\section{Russell versus Dewey on Democracy}

\section{Michael J. Rockler, National-Louis University}

\section{Introduction}

Philosophers Bertrand Russell and John Dewey contributed much to the intellectual history of the twentieth century. These great thinkers, whose lives overlapped, shared many interests. Their influence went beyond technical philosophy into the realms of social policy and politics where both men exercised influence in significant ways. Both were liberal political thinkers who wished to create a more equitable society; both attempted to define and articulate the nature and meaning of democracy.

John Dewey produced important perspectives on democracy, education, and knowledge despite being often less than clear in his thinking and writing. Gutek tells us that educators sometimes "did not accept Dewey's entire philosophy because they did not understand his difficult and often confusing prose" (Gutek, 1991, p. 342). Bertrand Russell was a clear and concise writer and thinker. His ideas remain valuable, helpful, and accessible to the modern reader. For most, Dewey must be interpreted in order to be understood.

A careful reading of Dewey on democracy demonstrates limits to his views; sometimes, these are obscured by his style. Russell, on the other hand, can offer contemporary readers important insights into life within a democratic society. Russell provides an understanding of the strengths and weaknesses of democracy in all its complexity; Dewey often makes assumptions about society which have lost their relevance as social life has become more complex.

In writing about Dewey, Russell said:

John Dewey, who was born in 1859 , is generally admitted to be the leading living philosopher of America. In this estimate, I entirely concur . . . He is a man of the highest character, liberal in outlook, generous and kind in personal relations, indefatigable in work. With most of his opinions, I am almost in complete agreement. Owing to my respect and admiration for him .... I should wish to agree completely, but to my regret I am compelled to dissent from his most distinctive philosophical doctrine, namely the substitution of "inquiry" for "truth" as the fundamental concept of logic and theory of knowledge. (Russell, 1945, p. 819)

This dissent of Russell's from Dewey's pragmatism is only one of the major differences between them on many issues relating to democratic theory.

\section{The Individual Citizen versus Membership in Society}

Bertrand Russell's second major book on education, Education and the Social Order, begins by asking a fundamental question: Should schooling train good individuals or good members of the society? In a perfect society, Russell concedes, there would be no difference between the two; but since this is not an ideal world, the question is legitimate. Russell argues that governments prefer citizens who support the status quo and want to preserve it. He views education as a conservative, almost reactionary force.

In the last chapter of Education and the Social Order, Russell rephrases the question. He asks, "Can the fullest individual development be combined with a necessary minimum of social coherence?"' Russell feels that this can 
only occur when the state identifies its own interests with that of the citizen and he is pessimistic about this possibility. Russell feels that this can only happen under specified conditions. These include the elimination of large scale wars, the eradication of superstition, and the avoidance of too great a commitment to uniformity. Russell doubts whether these prerequisites can be achieved. This was written in 1932 and, more than sixty years later, little progress seems to have been made. Although humankind may have eliminated large scale wars, the violent settlement of disputes remains a standard operating procedure for most countries despite the existence of the United Nations. While generally pessimistic about this issue, Russell does believe that human beings can be rational and that reason applied to education can result in a better world in which individuality can be reconciled with membership in the greater life of society.

Russell makes two important points about social coherence. First, the question of individuality versus social coherence is an important one to examine. Russell knows that membership in any society limits individuality to some degree. While never an anarchist, Russell urges caution about the ways in which individuals respond to the needs of the state. Second, Russell uses this discussion in Education and the Social Order to alert readers to the limits of any government. Russell distrusts governments and sees them as a necessary evil at best. For Russell, this is true about all governments whether democratic or totalitarian. The identity of the individual needs to be maintained and the rules by which individuals participate in society must be clearly defined.

Dewey never seems to voice these kinds of reservations and, in fact, emphasizes social life as the primary good. This point is made often and in many contexts. Listen to Dewey's views on the issue in My Pedagogic Creed:

In sum, I believe that the individual who is to be educated is a social individual, and that society is an organic union of individuals. (Dewey, 1964, p. 429)

This is an interesting statement. What does it mean to be "an organic union of individuals?" This kind of notion was adopted by the fascists in the 1930s. I do not in any way wish to accuse Dewey of fascism or anti-democratic views. But I believe that Dewey underestimated the problems that could be associated with creating a society that contained an imbalance which favoured the state over the individual. This imbalance is a problem that concerned Russell throughout his life. writes:

Dewey returns to this theme at least twice in My Pedagogic Creed. He

[I believe that] education is a regulation of the process of coming to share in the social consciousness; and that the adjustment of individual activity on the basis of this social consciousness is the only sure method of social reconstruction. (Dewey, 1964, p. 437)

And again in the same essay:

[I believe that] every teacher should realize the dignity of his calling; that he is a social servant set apart for the maintenance of proper social order and the securing of the right social growth. (Dewey, 1964, p. 439)

This passage contains disturbing phrases. What is "proper social order?" Russell would argue that the social order is multifaceted. What is proper is relative and is, therefore, very hard to determine. Russell's views on marriage, for 
example, created problems for him because they seemed to go against "proper social order." Whatever Dewey meant by this, it is a dangerous phrase-even more so for one who is considered to be an apostle of democracy. The same objection can be raised with regard to the phrase, "right social growth." What kind of social growth is not right and who determines it?

\section{In Democracy and Education, Dewey writes:}

As soon as he is possessed by the emotional attitude of the group, he will be alert to recognize the special ends at which it aims and the means employed to secure success. His beliefs and ideas, in other words, will take a form similar to those of others in the group. He will also achieve pretty much the same stock of knowledge since that knowledge is an ingredient of his habitual pursuits. (Dewey, 1966. p. 14)

Here again Dewey creates a problematic construction. To be possessed by the emotional attitude of a group is to lose, at least to some extent, one's individuality. The same holds true of the notion that one's beliefs and ideas will take a form similar to others in the group.

While group process and even group social life is a significant aspect of democratic social life, it is important that one maintain one's individual identity in the face of group emotions, beliefs, and ideas. Unless individuals are able to do this, mobocracy results-what Russell called rule by the "herd instinct." Dewey seems so enamoured of the need for social coherence that he seems to lose sight, at least in these statements, of what Russell called "fullest individual development."

A clear difference between Russell and Dewey emerges. Both Russell and Dewey respect individual rights and see the need for social coherence. Russell opts for the greater protection of individuals while Dewey is willing to sacrifice individual identity for an "organic union of individuals."

\section{Simplicity, Complexity and the Limits of Democracy}

One way to understand the difference in perspective on democracy between Bertrand Russell and John Dewey is to examine their respective backgrounds. Jobn Dewey was born in Burlington, Vermont on October 20, 1859. His parents were both the children of rural parents who were raised on farms. After their marriage, Archibald and Lucina Dewey began to operate a small grocery store in Burlington. Gutek tells us:

The Deweys were members of the Congregational church. Life in smalltown Vermont had an important impact on Dewey who, throughout his life, cherished a vision of the face to face, town meeting type of community that existed in New England. This vision of the small-town community may have influenced his emphasis on the role of the community in shaping social intelligence and participation. (Gutek, 1991, p. 333)

Bertrand Russell was born in 1872; his parents were British aristocrats. By the time Russell reached the age of four, his mother and father had both died. Russell was sent to live with his grandparents at their home in Pembroke Lodge. Young Bertrand's grandfather had been prime minister of England; the environment that Russell grew up in was one that continually challenged him intellectually.

This contrast in background-Dewey a child raised by grocers in a small 
community, Russell, a child raised by British aristocrats who were politically active-helps to explain another difference between Russell and Dewey. Dewey's background led him to see democracy in a relatively simple way; he often failed to perceive its complexities. Russell, on the other hand, saw democracy as a much more complicated and sophisticated process and was, therefore, able to see the limits of democracy in ways that probably seemed heretical to Dewey.

One example of Dewey's oversimplified view of democracy can be seen in the following passage from Democracy and Education. Dewey writes:

Individuals are certainly interested, at times, in having their own way, and their own way may go contrary to the ways of others. But they are also interested and chiefly interested upon the whole, in entering into the activities of others and taking part in cojoint and co-operative doings. (Dewey, 1966, p. 24)

Thus, Dewey's New England upbringing leads him to believe that co-operative and cojoint activity is the default position among human beings. This is a relatively naive view.

Of course, Russell is a strong supporter of democracy. He says, for example:

This is not to say that there is a better form of government. It is only to say that there are issues as to which men will fight, and when they arise no form of government can prevent civil war. One of the most important purposes of government should be to prevent issues from becoming so acute as to lead to civil war; and from this point of view, democracy, where it is habitual, is probably preferable to any other known form of government. (Russell, 1992, p. 131)

While this quotation endorses democracy as the most acceptable form of government, Russell offers a realistic view of its limits.

Russell was twice imprisoned by British governments because of his opinions. He was also refused a position at the College of the City of New York because of his writings. Thus, Russell understands an aspect of democracy experientially which Dewey can only understand intellectually (if he can understand it at all). Russell writes:

The most difficult kind of liberty to preserve in a democracy is the kind which derives its importance from services to the community that are not very obvious to ignorant people. New intellectual work is almost always unpopular because it is subversive of deep-seated prejudices, and appears to the uneducated as wanton wickedness. (Russell, 1994, p. 101)

It is clear from this passage, and others in his work, that Russell sees government, democratic or otherwise, as a distinct form of activity which affects persons but is outside of their usual lives. Government, at its best, can serve people but it must always be regarded with a degree of suspicion. While Russell is neither an anarchist nor a totalitarian, he understands the limits of government and its tendency to become corrupt.

Contrast this relatively sophisticated understanding with the following passage from Dewey:

A democracy is more than a form of government; it is primarily a mode of associated living, of conjoint communicated experience. (Dewey, 1966, p. 87) 
Another example of oversimplification by Dewey occurs in School and Society. Dewey writes:

A society is a number of people held together because they are working along common lines, in a common spirit, and with reference to common aims. (Dewey, 1990, p. 14)

Again, this is an oversimplified view of a complex phenomenon. The definition of society must be broader and recognize ways in which people in the same society have conflicting aims and interests. Generally, this passage is consistent with Dewey's tendency to see society-the state and the government-as benign. Compare this view with the following quotation from Russell's Power:

One of the advantages of democracy, from the governmental point of view, is that it makes the average citizen easier to deceive, since he regards the government as his government. Opposition to a war which is not swiftly successful arises much less readily in a democracy than under any other form of constitution. In a democracy, a majority can only turn against the government by first admitting to themselves that they were mistaken in formerly thinking well of their chosen leaders, which is difficult and unpleasant. (Russell, 1992, pp. 96-7)

Russell repeatedly affirms his commitment to democracy, but he is more able and more willing than Dewey to describe the limitations of democracy.

In Power, Russell also examines the notion that power is unevenly divided, even in a democracy. Dewey does not choose to discuss this issue. But Russell offers readers a more secure opportunity to live successfully in a democratic society when he tells them:

The members of the government have more power than the others, even if they are democratically elected; and so do officials appointed by a democratically elected government. The larger the organization, the greater the power of the executive. Thus, every increase in the size of organizations increases inequalities of power by simultaneously diminishing the independence of ordinary members and enlarging the scope of the initiative of the government. (Russell, 1992, p. 108)

In the first chapter of Education and the Good Life, Russell argues that an ideal system of education should be democratic. However, he warns that the existence of democratic procedures should not lead to a "dead level of uniformity." This is necessary, Russell tells us, because "some boys and girls are cleverer than others."

In his second major work on education, Education and the Social Order, Russell returns to this theme in still another way. He writes:

The error of aristocracy lay, not in thinking that some men are superior to others, but in supposing superiority to be hereditary. The error of democracy lies in regarding all claims to superiority as just grounds for the resentment of the herd. In the modern world, much work which is necessary to the community requires more ability that most men possess, and there must be ways of selecting exceptional men to do this work. In general, if they are to be as well qualified as possible, it is desirable to select them while they are still young - say twelve years old-and to allow them to make much more rapid progress than is possible to a class of average boys or girls. The feeling that it is undemocratic to single out the best pupils is one which leads to great waste of good material. (Russell, 1977, p. 54-5) 
Both Russell and Dewey were committed to democracy and recognized its value, even its superiority as a form of government. Dewey, however, tended to see democracy as an almost perfectly positive form of government which could be extended from government to society in general. Russell, on the other hand, recognized that any form of government is administered by human beings who have limits. Thus, Russell suggests that we proceed with caution as we create institutions in a democratic society. Dewey is far less cautious. This difference can be seen with regard to schooling as Russell maintains that children can be differentiated with regard to ability. Dewey, who is much more process oriented and much less concerned about subject matter, would probably take issue with this assertion.

\section{Democracy, Pragmatism, and the Herd Instinct}

One fundamental difference between Russell and Dewey comes from Russell's aversion to pragmatism. Both Russell and Dewey sought to come to terms with David Hume's critique of induction which had threatened the foundations of scientific thought. Hume had demonstrated that induction-the belief that general principles could be obtained from specific instances-was not logically defensible. Hume's critique, which had been ignored, began to be taken more seriously when Einstein demonstrated that Newtonian physics was fallible.

Russell, who provides considerable support in his writings for a strong sense of skepticism, came to the conclusion that induction could be accepted as an expedient in order to further the ends of scientific progress and knowledge. Russell also supports the process of falsification developed by Karl Popper. Dewey, in response to Hume, adopted the concept of "pragmatic truth." This point of view held that whatever worked was true as long as it functioned. When it no longer worked, it was replaced by a new truth. For Russell, this meant that truth was reduced to whatever the majority believed it to be. He concluded that pragmatism meant that knowledge was determined by power. $\mathrm{He}$ puts it in an interesting way in Sceptical Essays:

In practice, however, pragmatism has a more sinister side. The truth, it says, is what pays in the way of beliefs. (Russell, 1985, p. 49)

For Russell, pragmatism represented a misapplication of democracy. He opposed the notion that truth be democratically determined. Russell believed that there must be some valid external criteria for understanding reality. He once wrote, "William James preached the will to believe. I wish to preach the will to doubt." Russell ultimately rejected pragmatism because of his distrust of what he called the "herd instinct"--the tendency of masses of persons to go unthinkingly in a single direction. Thus, while Dewey pushed the concept of "democracy in education," Russell opposed pragmatism and was much more cautious about the extent to which schooling could be democratized.

In Democracy and Education, Dewey writes:

The theory of the method of knowing which is advanced in these pages may be termed pragmatic .... Knowledge as an act is bringing some of our dispositions to consciousness with a view to straightening out a perplexity, by conceiving the connection between ourselves and the world in which we live .... In an analogous way, since democracy stands in principle for free interchange, for social continuity, it must develop a theory of knowledge 
which sees in knowledge the method by which one experience is made available in giving direction and meaning to another. (Dewey, 1966, pp. 344-345)

For Dewey, knowledge is not objective but constructed; and in a democratic society it is constructed by the people through a kind of majority consensus. Gutek describes Dewey's approach to pragmatism as one in which "truth is tentative, a warranted assertion rather than universal and absolute" (Gutek, 1991, p. 336).

In A History of Western Philosophy, Russell comments:

[Dewey's] philosophy is a power philosophy, though not, like Nietzsche's, a philosophy of individual power, it is the power of the community that is felt to be valuable. It is this element of social power that seems to me to make the philosophy of instrumentalism attractive .... (Russell, 1945, p. 827)

Both Russell and Dewey appreciate the value of democracy as a form of government. For both thinkers, it is the only legitimate way for human beings to organize governance. But Russell views democracy as a system which has limits and for the most part should be confined to goveming the state. For Dewey, democracy can be applied broadly from education to the definition of truth. This can lead to schools without standards and to a definition of truth which is dependent on majority rule.

\section{Russell versus Dewey on Plato}

When one examines their respective views on Plato, one can see yet another difference between Russell and Dewey with regard to democracy. Plato opposed the Athenian democracy and created in The Republic a totalitarian state which was highly stratified and which sought to control the popular will. The society which Plato envisions lacks civil liberties and has a government of elitist philosopher kings who monitor all aspects of human life. Plato's republic could well serve as a model for Nazi Germany or Stalin's Soviet Union even as it was modelled on the totalitarian system of Sparta rather than the more open ended society of Athens. Russell has no difficulty seeing the limits of Plato:

It is not, therefore, surprising that he should turn to Sparta for an adumbration of his ideal commonwealth. Plato possessed the art to dress up illiberal suggestions in such a way that they deceived future ages, which admired the Republic without ever becoming aware of what was involved in its proposals. It has always been correct to praise Plato but not to understand him. This is the common fate of great men. My object is the opposite. I wish to understand him but to treat him with as little reverence as if he were a contemporary English or American advocate of totalitarianism. (Russell, 1945, p. 105)

Russell carefully analyzes and demonstrates the limits of Plato as a philosopher and as a political theorist. As for the use of philosopher kings to govern society, Russell says:

The problem of finding a collection of "wise" men and leaving the government to them is thus an insoluble one. That is the ultimate reason for democracy. (Russell, 1945, p. 107)

Dewey, on the other hand, is part of the western philosophical tradition which has canonized Plato. In Democracy and Education, he writes: 
The first [theory] to be considered is that of Plato. No one could better express than did he the fact that a society is stably organized when each individual is doing that for which he has aptitude by nature in such a way as to be useful to others (or to contribute to the whole to which he belongs); and that it is the business of education to discover these aptitudes and progressively to train them for social use. (Dewey, 1966, p. 88)

Later in the same chapter, Dewey praises Plato further:

However, Plato suggested a way out. A few men, philosophers or lovers of wisdom-or truth-may by study learn at least in outline the proper patterns of true existence. If a powerful ruler should form a state after these patterns, then its regulations could be preserved. (Dewey, 1966, p. 89)

In fairness to Dewey, he does describe some of the limitations of Plato, but his tone, as indicated by these examples, is really one of reverence. Dewey can accept Plato for what he is-a creator of a fascist political system.

Here again, the contrast between Russell and Dewey is clear. Russell is always able to see the limits-of democracy, of pragmatism, and of Plato-in a clear and ultimately helpful way. He facilitates understanding for persons who want to comprehend democratic theory in order to strengthen democracy. It is ironic that Russell - the son of aristocrats-produced a critical understanding of democracy that is more accurate than did Dewey-the son of democrats.

\section{Conclusion}

Both John Dewey and Bertrand Russell sought to understand and explain the modern democratic state. Both viewed it in terms of its historical context and both were interested in relating democratic thought to the nature of schooling in a democratic society. Russell believed that democracy should be seen as a form of government. Dewey wished to extend democratic theory to the classroom and to a way of establishing truth. Russell was suspicious of the state; he believed that it must operate within well defined limits. For Dewey, the state was potentially benign; for Russell all governments-whether democratic or not-could create mischief for their citizens.

Russell believed that there would always be a conflict between the rights of individuals and the interests of the state. Dewey viewed the individual as part of a larger community. For Russell, the individual must be paramount; for Dewey, the individual could become part of a greater societal whole. Russell identified and feared the herd instinct in human beings. Humankind must always be on guard against tyranny which could result from majority rule. For Dewey, tyranny was somehow less imminent-hence, his more positive view of Plato. Dewey had a view of human nature derived from his origins in a small New England community. Ultimately, Russell overcame his aristocratic beginnings to become an advocate for the preservation of human rights. In the end, Dewey's perspective on democracy, while optimistic and expansive, seems less useful than Russell's. The modern world can be better served by Russell's critical analysis of democracy. And Russell is much more enjoyable to read! 


\section{Bibliography}

Dewey, J. (1966). Democracy and Education. New York: The Free Press. (Originally published, 1916.)

Dewey, J. (1964). John Dewey on Education: Selected writings. New York: Modern Library.

Dewey, J. (1990). The Child and the Curriculum and The School and Society. Chicago: The University of Chicago Press. (The School and Society originally published, 1900.)

Gutek, G.L. (1991). Cultural Foundations of Education: A Biographical Introduction. New York: Macmillan.

Russell, B. (1926). Education and the Good Life. London: Boni and Liveright, Inc.

Russell, B. (1977). Education and the Social Order. London: Unwin Paperbacks. (Originally published, 1932.)

Russell, B. (1994). Fact and Fiction. London: Routledge. (Originally published, 1961.)

Russell, B. (1945). A History of Western Philosophy. New York: Simon and Schuster 1938.)

Russell, B. (1992). Power. London: Routledge. (Originally published,

Russell, B. (1985). Sceptical Essays. London: Unwin Paperbacks. (Originally published, 1928.) 